\title{
Orchidioid fungi of the form-genus Rhizoctonia associated with the roots of Chloraea cuneata Lindl. from Araucanía, Chile
}

\section{Hongos orquidioides del género-forma Rhizoctonia asociados a las raíces de Chloraea cuneata Lindl. de la Araucanía, Chile}

\author{
Cristian Atala ${ }^{1 *}$, Guillermo Pereira ${ }^{2}$, Christian Romero ${ }^{3}$, Laureana Muñoz-Tapia ${ }^{1}$, Reinaldo Vargas $^{4}$ \\ \& LAURA M. SUZ ${ }^{5}$
}

${ }^{1}$ Laboratorio de Anatomía y Ecología Funcional de Plantas, Instituto de Biología, Facultad de Ciencias, Pontificia Universidad Católica de Valparaíso, Campus Curauma, Avenida Universidad 330, Valparaíso, Chile.

${ }^{2}$ Departamento de Ciencias y Tecnología Vegetal, Campus Los Ángeles, Universidad de Concepción, Chile, Casilla 234, Los Ángeles, Chile

${ }^{3}$ Departamento de Botánica, Facultad de Ciencias Naturales y Oceanográficas. Casilla 160-C. Universidad de Concepción, Concepción, Chile.

${ }^{4}$ Herbario Federico Johow, Departamento de Biología, Universidad Metropolitana de Ciencias de la Educación, Avda. José Pedro Alessandri 774, Ñuñoa, Santiago, Chile.

${ }^{5}$ Mycology, Royal Botanic Gardens Kew, Surrey TW9 3DS, UK.

*cristian.atala@ucv.cl.

\begin{abstract}
RESUMEN
Chloraea cuneata es una orquídea endémica de Chile en Peligro Crítico de Extinción. Se aislaron e identificaron hongos orquidioides a partir de pelotones ubicados en células corticales de sus raíces pertenecientes al género-forma Rhizoctonia, teleomorfo Thanatephorus (multinucleado), los que podrían ser usados en iniciativas de conservación.
\end{abstract}

Orchidaceae is one of the largest flowering plant Families in the world (Jones 1993, Dressler 1993, Heywood et al. 2007, Reina-Rodríguez et al. 2010), with an almost cosmopolite distribution (Novoa et al. 2006, Heywood et al. 2007). Orchidaceae in Chile are represented by 7 terrestrial genera: Aa, Bipinnula, Brachystele, Chloraea, Codonorchis, Gavilea, and Habenaria (Novoa et al. 2006). Chile has a high orchid endemism, with approximately half of the 54 Chilean species endemic to the country (Novoa et al. 2006). Many of these species are considered endangered or even critically endangered (Van Nieuwenhuizen 1998). However, the poor taxonomic and biological knowledge of the group makes it difficult to determine the conservation status of many taxa (Novoa 2008). Chloraea cuneata Lindl. (Fig. 1a) is an endemic and Critically Endangered orchid species from Chile (Novoa et al. 2006, Elórtegui \& Novoa 2009, MMA 2011). This species is a terrestrial and non-parasitic orchid (Correa 1969, Elórtegui \& Novoa 2009) found in Chile only in the Araucanía district $\left(\sim 39^{\circ} \mathrm{S}\right)$ with few known populations (Romero 2012).

Most terrestrial orchids depend on fungal partners to germinate and grow (Pereira et al. 2005, Murguía \& Lee 2007, Smith \& Read 2008, Steinfort et al. 2010, Valadares et al. 2012). This is due to the lack of nutritious reserves in their seeds (Smith \& Read 2008). In the soil, orchids commonly associate with Basidiomycota (McLaughlin \& Spatafora
2014) fungi from the form-genus Rhizoctonia (Otero et al. 2002, Durán et al. 2007, Otero \& Bayman 2009, Steinford et al. 2010, Pereira et al. 2014). This association is vital for plant success (Otero \& Bayman 2009) and can persist in the adult stage, where the cortical cells of the roots usually show hyphae clusters known as pelotons (Pereira et al. 2014). Some Chloraea species that co-occur with $C$. cuneata in the Araucanía district have been found to associate with orchidioid fungi belonging to the Tulasnellaceae (Pereira et al. 2014). These fungi show the typical traits of the formgenus Rhizoctonia; namely hyphae constriction in the septum, right-angle branching of hyphae, and presence of monilioid cells (García et al. 2006, Pereira et al. 2014).

The present study aims to isolate and identify possible fungal partners of $C$. cuneata. This could have relevant consequences for future conservation and propagation programs for this Critically Endangered species since reintroduction should include the inoculation of the substrates with the associated fungi.

Three tuberous roots from 2 individuals of $C$. cuneata we collected (Fig. 1a-b). The population was located at Nahuelbuta National Park (Araucanía Region) and consisted only in those 2 individuals. Root segments were cut in a laminar flux chamber and were externally sterilized by seriated ethanol baths (Otero et al. 2002, Otero \& Bayman 2009). Roots segments with evident hyphae pelotons inside 

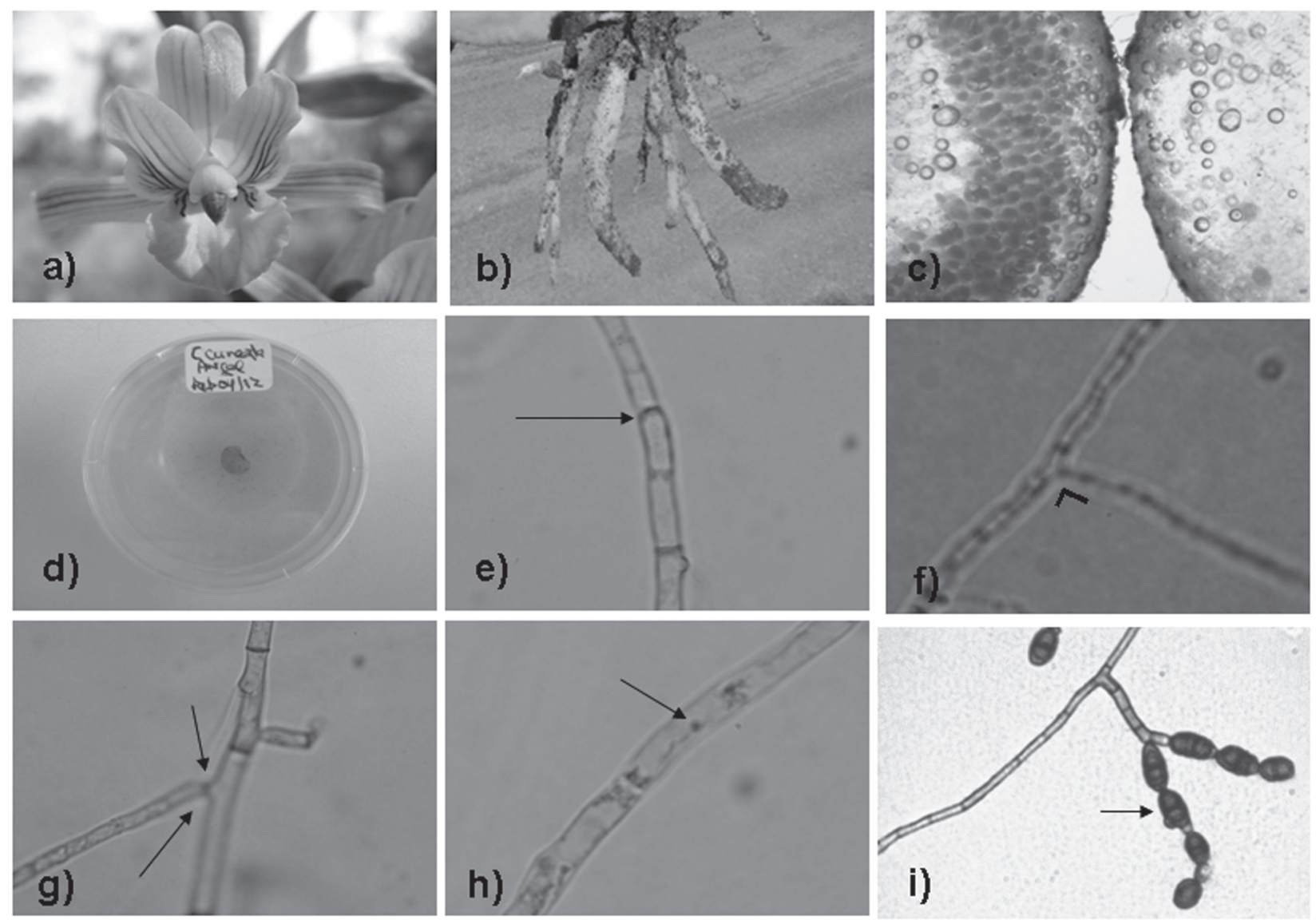

FiguRE 1. Flower (a), roots (b) and root section with presence of hyphae (c) of C. cuneata. Also, fungi isolated from C. cuneata roots are shown (d-i). Plate with fungal culture (d), hyphae morphology (e, f, g, h), and presence of monilioid cells (i).

Figura 1. Flores (a), raíces (b) y secciones de raíces con presencia de hifas (c) de C. cuneata. También se muestran hongos aislados de las raíces de C. cuneata (d-i). Placa con el cultivo fúngico (d), morfología de las hifas (e, f, g, h) y presencia de células monilioides (i).

cortical cells were cultured in Water-Agar (WA) and later re-cultured in Potato, Dextrose, Agar (PDA). All culture media were autoclaved at $121 \pm 1^{\circ} \mathrm{C}$ for $20 \mathrm{~min}$. The isolated material was incubated in the dark in a stove at $24 \pm 1{ }^{\circ} \mathrm{C}$ for 10 days. Pure fungal isolates were successfully obtained from each individual (from one root each). After 10 days, the microscopic traits of the fungal isolates were observed using an optic microscope (Primo Star, Carl Zeiss, Germany) attached to a digital camera (Canon EOS Rebel). Hyphae size was measured and nuclei number per cell in young hyphae was recorded in each isolate using image software (AxioVision rel. 4.8). The presence of monilioid cells and other possible morphological traits typical of Rhizoctonia were registered. The possible teleomorph was assigned based on the number of nuclei per cell (Currah et al. 1997, Pereira et al. 2014).

The roots of C. cuneata (Fig. 1b) showed presence of hyphae in their cortical cells. Pelotons (hyphae clusters) were evident inside those cells (Fig. 1c). From those pelotons, two fungal strains were isolated (Fig. 1d) both showing Rhizoctonia-like traits (Fig. 1e-i, Table I). The two isolates were coded as CCANG1 and CCANG2. Based on nuclei number per young hyphae, the isolates correspond to the Thanatephorus teleomorph (Table I). Both isolates showed similar hyphae traits (Table I, t-test $\mathrm{p}>0.05$ ) and presence of monilioid cells (Fig. 1i). There were no statistical differences between isolates in the measured fungal traits ( $\mathrm{t}$ test $\mathrm{p}>0.05, \mathrm{n}=30$ measurements per isolate, Table I).

Chloraea cuneata associates with orchidioid fungi of the form-genus Rhizoctonia. In particular, individuals from Araucanía Region were found to have their roots colonized by fungi that belong to the Thanatephorus teleomorph, which were identified according to the number of nuclei per cell and the presence of monilioid cells (Currah et al. 1997, Corrêa et al. 2011, Pereira et al. 2014). Previous studies on C. collicensis and C. gavilu have observed orchidioid fungi from the Tulasnellaceae, a family of Rhizoctonia-like fungi (Pereira et al. 2104). Other Chilean orchid species, however, have been found to associate with other Basidiomycota (Steinford et al. 2010). Many orchidioid fungi show Rhizoctonia-like traits (García et al. 2006, Pereira et al. 
TABLE I. Morphological traits of hyphae of two fungal strains isolated from the roots of Chloraea cuneata. Average values $\pm \mathrm{SE}$ of two independent isolates showing the same morphological traits are shown. Values correspond to the average of 30 measurements per isolate. For nuclei number/cell average values and range (inside brackets) are shown.

TABLA I. Características morfológicas de las hifas de dos cepas fúngicas aisladas de las raíces de C. cuneata. Se muestran valores promedio $\pm \mathrm{EE}$ (error estándar) de dos aislados independientes con los mismos rasgos morfológicos. Los valores corresponden al promedio de 30 mediciones por aislado. Para el número de núcleos/célula, se muestra el promedio y el rango (entre paréntesis).

\begin{tabular}{lccccc} 
Isolate & Hyphae Width (Mm) & Hyphae Length $(\mathrm{Mm})$ & Nuclei number/Cell & Monilioid cell & Possible teleomorph \\
\hline CCANG1 & $57.01 \pm 9.13$ & $115.64 \pm 23.61$ & Multinucleated & $1.9(1-3)$ & + \\
CCANG2 & $54.55 \pm 13.08$ & $119.97 \pm 24.07$ & Multinucleated & $1.5(1-3)$ & +
\end{tabular}

2014), but there is also evidence for non-Rhizoctonia fungi involved in orchid-fungi symbiosis (Darnaley 2007). It is possible that other fungal species can associate with $C$. cuneata in the field that can not be isolated by the methods used in this work. Also, the fungal partner may change with plant ontogeny and/or with environmental conditions (McCormick et al. 2006). In our lab we are currently testing the effect of the isolated fungi on seed germination. This will allow us to confirm if these fungi can colonize the seeds and induce their germination or if it is only found as a fungal partner in the adult (late association). Seemingly, this is the first report of orchidioid fungi (Rhizoctonia-like traits) present in the roots of $C$. cuneata.

Chloraea cuneata is a Critically Endangered species, with a very narrow distribution (MMA 2011, Romero 2012). Association with fungal partners can increase germination and growth of orchids (Pereira et al. 2005, Murguía \& Lee 2007, Smith \& Read 2008, Bidartondo \& Read 2008, Valadares et al. 2012) as well as survival under stress (Smith \& Read 2008). It is possible that the distribution and abundance of $C$. cuneata can be limited by the presence and abundance of specific orchidioid fungi in the soil (Ramsay \& Dixon 2003, Otero \& Bayman 2009). Thus, conservation initiatives could use the isolated fungi identified in our study in order to germinate seeds and inoculate adult plants for ex situ conservation and re-introduction programs. Pure cultures of the fungi are currently held at our laboratory for such initiatives.

\section{ACKNOWLEDGEMENTS}

We would like to thank CONAF Araucanía Region for field support. Funding was provided by Project PIAiniciación 037.480/2013 (PUCV) and Project DI-iniciación 037.371/2014 (PUCV).

\section{REFERENCES}

BidARTONDO, M.I. \& D.J. READ. 2008. Fungal specificity bottlenecks during orchid germination and development. Molecular Ecology 17: 3707-3716.

Correa, M. 1969. Chloraea género sudamericano de Orchidaceae. Darwiniana 15(3-4): 374-500.

Corrêa, M., N. Moreira, M. Rogêrio \& M.C. Megumi. 2011. Total fatty acid composition in the characterization and identification of orchid mycorrhizal fungi Epulorhiza spp. Revista Brasileira de Ciência do Solo 35: 1159-1165.

Currah, R.S., L.W. ZettLer \& T.M. McInNis. 1997. Epulorhiza inquilina sp. nov. from Platanthera (Orchidaceae) and a key to Epulorhiza species. Mycotaxon 61: 338-342.

Darnaley, J.D. 2007. Further advances in orchid mycorrhizal research. Mycorrhiza 17: 475-486.

Dressler, R.L. 1993. Phylogeny and classification of the orchid family. Dioscorides Press, Portland, OR, USA. 314 pp.

Durán, C., M. Rivero \& P. Seemann. 2007. Identificación de endomicorrizas en la orquídea nativa Gavilea araucana (Phil.) Correa. Agro Sur 35(2): 67-69.

Elórtegui, S. \& P. NovoA. 2009. Orquídeas de la Región de Valparaíso. Taller La Era. Viña de Mar, Chile. 82 pp.

García, V.G., M.A. Onco \& V.R. Susan. 2006. Biology and systematics of the form genus Rhizoctonia. Spanish Journal of Agricultural Research 4: 55-79.

Heywood, V.H., R.K. Brummitt, A. Culham \& O. Seberg. 2007. Flowering Plant Families of the World. Firefly Books. Ontario, Canada. 424 pp.

Jones, D.L. 1993. Native Orchids of Australia. Reed Books, Australia. 656 pp.

McCormick, M.K., D.F. Whigham, D. Sloan, K. O’Malley \& B. HodKINSON 2006. Orchid-fungus fidelity: a marriage meant to last? Ecology 87: 903-911.

McLaughlin, D.J. \& J.W. Spatafora. 2014. The Mycota. Volume VII. Systematics and Evolution Part A. Second Edition. Springer. $461 \mathrm{pp}$.

Ministerio del Medio Ambiente. 2011. Reglamento de clasificación de especies. Sexto Proceso de Clasificación de Especies Silvestres según Categoría de Conservación. Decreto 
Gayana Bot. 72(1), 2015

Supremo $N^{\circ}$ 41/2011, MMA.

Murguía, G.J. \& E.H. LeE. 2007. Manual de producción de orquídeas. Universidad Veracruzana, Xalapa, México. 75 pp.

NovoA, P. 2008. Catálogo histórico de las orquídeas de Chile. Boletín Jardín Botánico Nacional. Dendroseris I (2). 55 pp.

Novoa, P., J. Espejo, M. Cisternas, R. Rubio \& E. Domínguez. 2006. Guía de campo de las orquídeas chilenas. Ed. Corporación Chilena de la Madera. Concepción, Chile. 120 pp.

OTERo, J.T. \& P. BAYMAN. 2009. Germinación simbiótica y asimbiótica en semillas de orquídeas epífitas. Acta Agronomía 58(4): 270-276.

Otero, J.T., J.D. Ackerman \& P. Bayman. 2002. Diversity and host specificity of endophytic Rhizoctonia-Like fungi from tropical orchids. American Journal of Botany 89(11): 1852-1858.

Pereira, O.L., M.C. Magami, C. De Lima \& G. Montandon. 2005. Isolamento e identificação de fungos micorrízicos rizoctonióides associados a três espécies de orquídeas epífitas Neotropicais no Brasil. Revista Brasileira de Ciência do Solo 29: 191-197.

Pereira. G., C. Romero, L.M. Suz \& C. Atala. 2014. Essential mycorrhizal partners of the endemic Chilean orchids Chloraea collicensis and C. gavilu. Flora 209: 95-99.

Ramsay, M.M. \& K.W. Dixon. 2003. Propagation science, recovery and translocation of terrestrial orchids. In: K.W. Dixon, S.P.
Kell, R.L. Barret \& P.J. Cribb (eds.), Orchid conservation. Natural History Publications (Borneo), Kota Kinabalu, Sabah, 259-288 pp.

Reina-Rodríguez G.A， N.H. Ospina-Calderón, A. Casaño, I. Soriano \& J.T. Otero. 2010. Catálogo de las orquídeas del Valle Geográfico del Río Cauca y su piedemonte andino bajo, sur-occidente colombiano. Cespedesia 32: 1-21.

Romero, C. 2012. Orquídeas de Nahuelbuta, Símbolo de la Comuna de Angol. Fondo de Protección Ambiental. Ministerio de Medioambiente. Gobierno de Chile. 80 pp.

Smith, S.E. \& D.J. Read. 2008. Mycorrhizal symbiosis, $3^{\text {rd }}$ edn. Academic, San Diego, USA. 800 pp.

Steinfort, U., G. Verdugo, X. Besoain \& M. Cisternas. 2010. Mycorrhizal association and symbiotic germination of the terrestrial orchid Bipinnula fimbriata (Poepp.) Johnst. (Orchidaceae). Flora 205: 811-817.

Valadares, R.B., M.C. Pereira, J.T. Otero \& E.J. Cardoso. 2012. Narrow fungal mycorrhizal diversity in a population of the orchid Coppensia doniana. Biotropical 44: 114-122.

Van Nieuwenhuizen, G.W.J. 1998. Propuesta de estado de conservación de las orquídeas chilenas. En: P. Ravenna, S. Teillier, R. Macaya, R. Rodríguez \& O. Zöllner. Categorías de conservación de las plantas bulbosas nativas de Chile. Boletín Museo Nacional de Historia Natural 47: 47-68.

Recibido: 14.08 .14

Aceptado: 27.10.14 